\title{
The Free and Compulsory Education in Akwa Ibom State, Nigeria: A Panacea for National Development
}

\author{
Ubong Edem Effiong ${ }^{1 *}$, Ofonime Moses Akpan ${ }^{2}$ \\ ${ }^{1}$ Department of Economics, University of Uyo, P.M.B. 1017, Uyo, Akwa Ibom State, Nigeria \\ ${ }^{2}$ Department of Economics, School of Arts and Social Sciences, Colleges of Education, Afaha Nsit, Akwa Ibom State, Nigeria
}

\section{Article History}

Received: 18.09 .2020

Accepted: 05.10 .2020

Published: 10.10 .2020

Journal homepage: https://easpublisher.com/easjehl

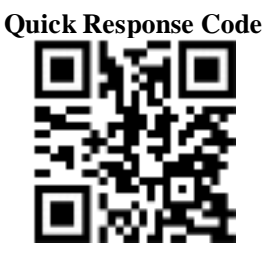

Abstract: This paper examined the impact of free and compulsory education in the development of Akwa Ibom State for the period 1997 to 2018. Data for the study were obtained from Federal Ministry of Education, National Bureau of Statistics, and UBE Digest. The study employed the $t$ - test approach so as to compare both the enrollment and completion rates in the primary and secondary school levels between the period before the implementation of the programme $(1997-2008)$ and the period during which the programme is being implemented (2009-2018). The result shows that both the enrollment and completion rates differs significantly between the period before the introduction of free and compulsory education and the period of the programme at the secondary school level. However, it was observed that the programme exerted no significant influence at the primary school level. It follows from the findings that the implementation of the free and compulsory education in the state is of great importance as it strives to eradicate illiteracy and prepare the future generations to greatness. The paper concludes that resources availability relates significantly with effective implementation and achievement of the goal of free and compulsory education in Akwa Ibom State. Thus, efforts geared towards adequate provision of educational resources should be made towards meeting the ever increasing enrollment rates in the school system.

Keywords: Free Education, National Development, t-test, Educational Resources, Akwa Ibom State.

Copyright (C) 2020 The Author(s): This is an open-access article distributed under the terms of the Creative Commons Attribution 4.0 International License (CC BY-NC 4.0) which permits unrestricted use, distribution, and reproduction in any medium for non-commercial use provided the original author and source are credited.

\section{INTRODUCTION}

Formal education is regarded as one of the ways of developing sound human capital for the growth and development of any nation. According to [1], education is a major investment in human capital development and it plays a crucial role in long-term productivity and growth at both micro and macro levels. Thus, provision of quality education in Akwa Ibom State in particular, and Nigeria in general has been a matter of public discourse at all levels. This approach of human capital development is achieved through the utilization of sound educational resources. Educational resources are the human and technical capitals used in the attainment of educational goals and objectives [2]. In as much as input affect output, the degree of provision and utilization of educational resources may affect the performance of school and its programmes. However, the utilization of such education resources is bound to be influenced by its availability, the characteristics of the educational resources, the objectives of the educational programmes, and the level of civilization [3].

Presently, the objective of the free and compulsory education programme is to provide education (both in quality and quantity) to all the residents within the boundaries of the state, irrespective of the state of origin, so as to eradicate illiteracy. Provision of quality education has been ranked as the best legacy any reliable leader, government or parent could leave for her/his people because it determines the standard of growth achieved. No wonder as far back as 1981, the Federal Government of Nigeria issued a statement that education has been adopted as an instrument par excellence for effective national development.

As noted by Otu, S. O. et al., [4], the benefits of education do not only include freedom from ignorance and superstitious beliefs rather, it inculcates freedom of the mind for quicker perception of issues; inspires the spirit of enquiry and experimentation; and 
stimulates creativity and innovation. The provision of quality free and compulsory education entails the removal of every socio-cultural impediment to education. It is backed up by the establishment of various kinds of schools and expansion of school curriculum to make each child develop according to his or her ability, age and interest [5]. Such programme is supported with the establishment and provision of library facilities, technical and vocational equipment, recruitment and retention of qualified and adequate man power, free tuition, free feeding, free books, free accommodation, free transportation, uniform and other personal needs of the learners.

Provision of education for the citizens is a constitutional right that should not be infringed. Meanwhile, education in Nigeria has been regarded to be free and compulsory up to the senior secondary level, with substantial subsidization at the tertiary level. Right from 1999, the Universal Basic Education (UBE) Scheme was launched with the aim of providing free and compulsory universal basic education for every Nigerian of school-going age. This is also backed by section 18(3) of the 1999 constitution of the Federal Republic of Nigeria that reiterates the mandate of the government to eradicate illiteracy by providing free, compulsory and universal primary education; free secondary education; and free adult literacy programme.

A lot of declarations at the international community have been made pertaining to education. These include The Jomtein Declaration of 1999 on the promotion of basic education for all; the New Delhi Declaration of 1991 requiring stringent effort by the E-9 countries to drastically reduce illiteracy within the shortest time frame [6]; and even the Vision 20-2020. The launching of the Universal Basic Education Programme was a strong evidence of Nigeria's commitment to the aforementioned international conventions for the promotion of Basic Education in the country.
As noted by Salami, K. A. [6], the Universal Declaration of Human Rights Act which emanated from World Conference on 'Education For All (EFA)', held in Jomtien, Thailand in 1990, gave rise to the universal, free and compulsory education in Nigeria. This program was launched by the then President of the Federal Republic of Nigeria, Chief Olusegun Matthew Obasanjo on September, 30th 1999. This was subsequently signed into law in May, 2004 [7]. The aim of the scheme was to make education universal, free and also compulsory from primary up to the junior secondary schools for all Nigerians irrespective of age, sex, race, religion, occupation or location. The UBE would thus, lay the foundation for basic literacy, numeracy and communication in the society [8].

In compliance and complementing the Federal Government's efforts, several states key into the programme. Akwa Ibom State, under the leadership of Governor Gods'will Obot Akpabio in 2009, keyed into the programme by declaring a free and compulsory education from primary to secondary levels. Such gesture was followed with the distribution of free exercise books to schools; science and technology equipment for science laboratories and technology workshops; books for libraries; payments of subventions to schools; and payment of students' final examination registration fees. Also, children of school age were banned from street hawking within school hours with offender/parents duly dealt with if the order is compromised. According to the then Governor, illiteracy compound poverty, while education does not only enlighten but also empowers.

The implementation of the free and compulsory education in the State witnessed tremendous changes in enrollment at both the primary and secondary levels. Statistic from the Federal Ministry of Education [9] indicates a significant increase in both male and female enrollments. Figure-1 represents the enrollment in the State after two years of implementation of the programme.

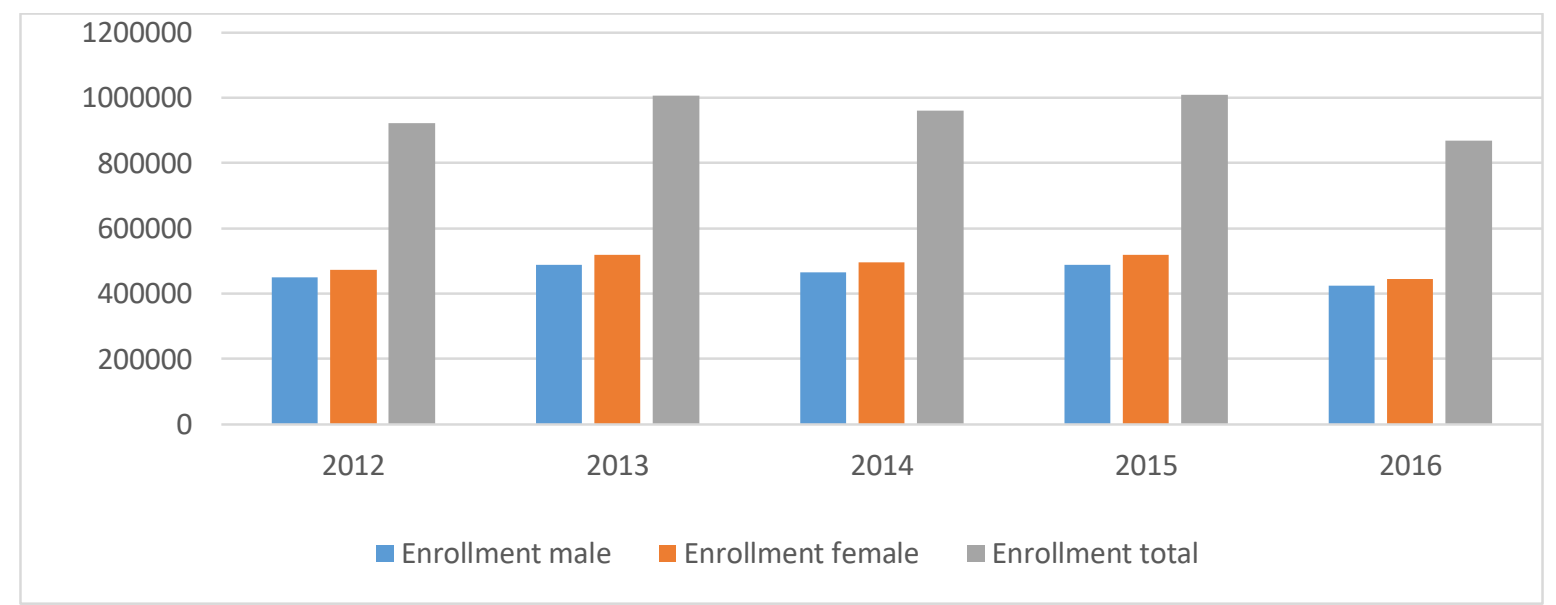

Fig-1: Primary School Enrolment in Akwa Ibom State by Year and Gender: 2012-2016 
Figure-1 indicates that total enrollment in the state reached one million as at 2013 with a varying proportion of male and female enrollments. Take for instance, male enrollment stood at 448,519 in 2012 and increased to 488,717 in 2015 representing $8.96 \%$ increase; but declined to 424,274 in 2016 . In the same vein, female enrollment stood at 472,984 in 2012 but recorded an upsurge to 519,622 in 2015 and declined to 443,875 in 2016 . Total enrollment stood at $1,008,339$ in 2015 and declined to 868,149 in 2016 [9].

A similar increase in enrollment was observed at the junior secondary level. Evidence is presented in Figure-2.

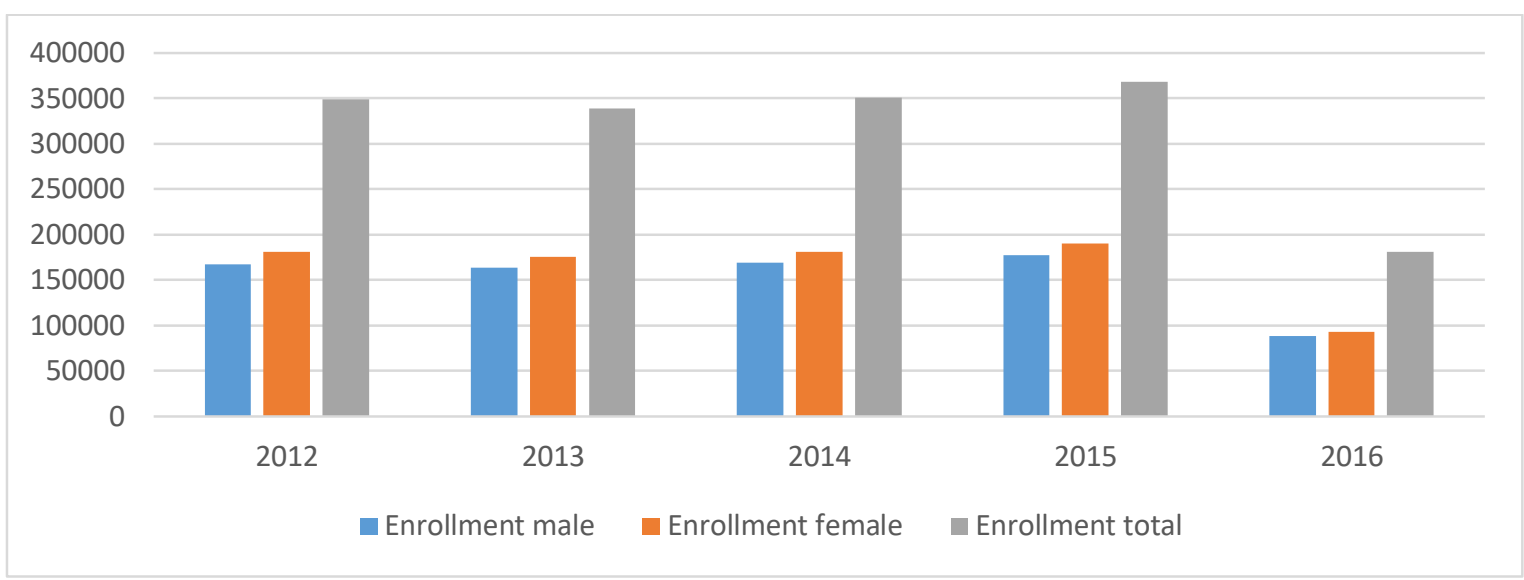

Fig-2: Junior Secondary School Enrolment in Akwa Ibom State by Year and Gender: 2012-2016

A glance at Figure-2 shows that male enrollment stood at 167,075 students in 2012 but increased to 177,488 in 2015 and a record low of 88,500 students in 2016. Female enrollment was 181,236 students in 2012 but increased to 190,263 in 2015 and declined to 92,432 students in 2016. Total enrollment averaged 317,122 students over the five - year's period. The drastic decline in enrollment as at 2016 is an indication that a large chunk of children who were not in school have taken advantage of the free and compulsory education at the earlier stage of introduction, making subsequent year's enrollment to shrink.

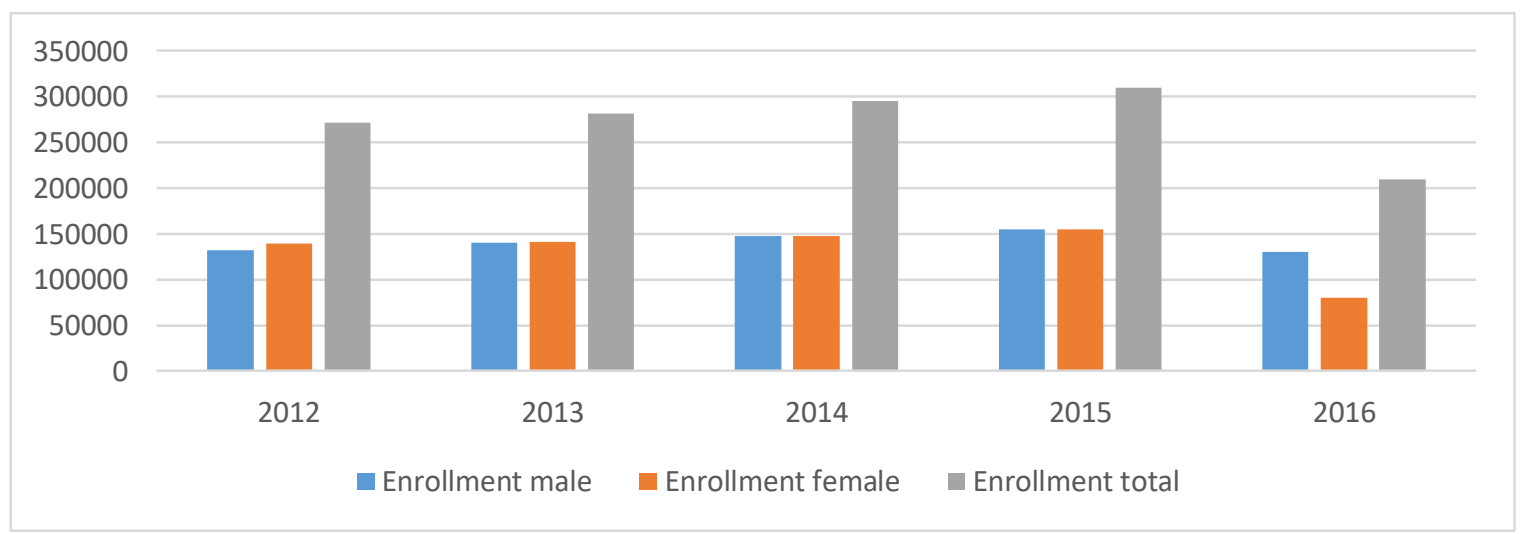

Fig-3: Senior Secondary School Enrolment in Akwa Ibom State by year and Gender: 2012-2016

At the senior secondary level, male enrollment stood at 140,336 in 2013 and increased to 154,729 in 2015 but declined to 130,116 students in 2016 . Also, female enrollment stood at 139,717 students in 2012 but increased to 155,368 students in 2015 but pictured a decline to 79,775 students in 2016. Total secondary school enrollment stood at 271,843 students in 2012 but increased to 310,097 students in 2015 and then decline to 209,891 students in 2016 [9].

One common feature that can be noted from the above statistic is that female enrollment always exceed male enrollment indicating some degree of gender disparity in education attainment. This therefore point out the predominance of female education in the state over that of male. The Federal Ministry of Education [9] put the net enrollment ratio for the male to be 94.73 and female to be 93.50 while the gross enrollment ratio was 102.54 for male and 110.87 for female at the primary school level. In this category as well, the completion rate for male was put at 89.28 and that of female to be 95.74. At the junior secondary level, the gross enrollment ratio for male was put at 43.73 and that of female to be 47.20 while the completion rate was put at 45.74 and 42.27 for male and female junior secondary school students respectively. 
The implementation of free and compulsory education in Akwa Ibom State has recorded a high degree of positive comments from people within and outside the state. However, this has not been matched with substantial educational resource. As generally argued, there is a wide gap between the policy formulation and implementation. There have been records of some schools marked with overpopulation with students sitting on the windows and some under the trees to receive lessons. As noted by Obanya, P. A. [10], the aims and objectives of free and compulsory education programme are capable of being achieved if the government adopts more appropriate approaches for improving public enlightenment and social mobilization for community involvement; engage in data collection and analysis; get experts involvement in planning; monitoring and evaluation; prudently handle teacher's recruitment, education, training and retraining and motivating teachers for high productivity; provide infrastructural facilities; enriched curricula; text books and instructional materials; as well as improving funding and management of the entire process. In the situation where these educational infrastructures became inadequate, such challenges are bound to impede the successful implementation of the programme and its attendant importance to the development of the state.

From the foregoing, key questions become pertinent. These are:

i. Does the free and compulsory education influence the development of Akwa Ibom State:

ii. Doe the free and compulsory education programme influence school enrollment?

iii. Has the free and compulsory education programme affect school completion rate?

This paper therefore seeks to investigate the effect of the free and compulsory education programme on the development of Akwa Ibom State. The specific objectives include:

i. To ascertain the effects of free and compulsory education on school enrollment in Akwa Ibom State.

ii. To examine the impact of free and compulsory education on the secondary school completion rate.

The following null hypotheses will be tested in the course of this study:

i. There is no significant effect of free and compulsory education in Akwa Ibom State on school enrollment at the primary school level.

ii. There is no significant effect of free and compulsory education in Akwa Ibom State on school enrollment at the junior secondary school level.

iii. There is no significant effect of free and compulsory education in Akwa Ibom State on school enrollment at the senior secondary school level.

iv. There is no significant effect of free and compulsory education in Akwa Ibom State on the senior secondary school completion rate.

Since education is a key variable in transforming a nation into a civilized one, this study is therefore significant in the sense that it brings to the fore, the need for sustainable and qualitative education as it is a veritable tool for development. This study will bring policy recommendations that will help the government in promoting continuous qualitative education for all. It will also elicit vital information about the educational attainment of the state and the need to invest ideally in the area of labour absorption as the state is filled with best brains that can shape the affairs of the country but however, left unutilized.

\section{LITERATURE REVIEW}

The theories on education can be linked to theories of human capital development. However, education should be viewed as an investment good. The investment in education is likened to the accumulation of human capital with a view to receive a higher income afterwards [11, 12]. Since education is an investment good, there is both a demand and supply implications. The demand for education is determined by equating the marginal cost of education (consisting of direct cost, like tuition fees, and opportunity cost arising from foregone income) to the marginal benefits due to a higher present value of lifetime income. As expected, the demand for education depends negatively on the interest rate and both direct and indirect cost [13, 14]. The higher marginal cost of education relative to the marginal benefit, the lower will be the demand for education. Since education is affected by the cost (in this case the price), then it follows that education is affected by wealth. However, Kodde, D. A. [15] noted that while initial wealth has no impact on the decision on receiving education under perfect information, the corresponding demand elasticity is positive under uncertainty about future wage rates. A positive impact of wealth on the demand for education also occurs if individuals are liquidity constrained.

Also, education can be viewed as a consumption good [12, 17]. It therefore follows that there is an observable positive income effect with respect to the demand for education. A high demand for education can also signal a high productivity to potential employers [18-20]. The main idea starts from the premise that firms cannot observe the productivity of their workers directly. At the firm level, educated 
individuals are more likely to choose input combinations that minimizes cost [21]; and in the household production, there is bound to be a rising productivity $[22,23]$.

The role of human capital development and economic growth and development have received series of empirical attention. Babatunde, M. A et al., [24] discovered a long-run relationship between human capital development (school's enrollment in primary and tertiary institutions and average years of schooling) and economic growth measured per worker. Their result showed that education has a statistically significant positive relationship with economic growth. Lawanson, O. I. [25] examined the role of human capital investment on economic growth in Nigeria and found out that a clear relationship exists between human capital development and economic growth.

Akpabio, I. U et al., [26] investigated the implementation of the free and compulsory education at the secondary school level by adopting an ex-post facto correlational research design. The result of the data analysis using Pearson's Product Moment Correlation obtained revealed that there is a significant relationship between resource availability and implementation of free and compulsory education at the secondary school level in Akwa Ibom State in terms of availability of teachers (0.95); availability of fund (0.97) availability of facilities and instructional materials (0.96). They therefore recommend that at least $25 \%$ of the annual budget should judiciously be allocated, disbursed and spent on Free and compulsory Education.

Olefero, N. A et al., [27] examine massification of students' intake and effectiveness of administration in public secondary schools in Akwa Ibom state, Nigeria using an ex-post facto correlational design was used for the study. The study shows a weak positive relationship between students' massification and principals' supervision. The study also reveals a very weak relationship between students' massification and principals' supply of school facilities. The study further shows a very weak relationship between students' massification and principals' managing of school budget. It was recommended based on the findings that administrators and all heads of schools should not panic whenever there is influx of students in their school enrolment. Rather, when faced with such a challenge, should look for the best way to tackle that administrative responsibility by looking inward. They also recommend that the State Secondary Education Board should have some incentives to use and encourage principals who manage their schools without much demand on the government.

\section{Methodology}

This study employs the student's $\mathrm{t}$ - test in the data analysis. This is to enable the comparison between the period before the free and compulsory education (1997 to 2007) and the period of free and compulsory education (2008 to 2018) as it affects enrollment and completion rates. The data in this study are secondary data obtained from $[28,9,29,30]$.

This study has samples from two independent groups like experimental (period of free and compulsory education) and control (period of no free and compulsory education). The student's t-test developed by Fisher is the appropriate statistical method for independent groups or samples. This study employs the independent t-test. The t-test is based on various assumptions as specified as follows:

i. There must be two groups whose means are compared for a possible difference.

ii. The two groups are independent. That is, the observations in population 1 are independent of the observation in population 2 .

iii. The population variance of the two groups are assumed to be equal. This is often referred to as homogeneity of variance.

iv. Assignment of individual into the two groups is randomly and independently done.

v. Data for the t-test are continuous or interval.

Whenever the t-test is used, it is proper that the researcher provides the means, standard deviation and $\mathrm{N}$ as well as the formula for the t-test used.

The formula for the t-test is given as follows:

$$
\mathrm{t}=\frac{|\varphi-\omega|}{\sqrt{\frac{\sigma a^{2}}{N a}+\frac{\sigma b^{2}}{N b}}}
$$

Where:

$$
\begin{aligned}
& \mathrm{t}=\text { student's calculated } \mathrm{t}-\text { value } \\
& \varphi=\text { Mean of sample A } \\
& \omega=\text { Mean of sample B } \\
& \sigma a^{2}=\text { Variance of sample A } \\
& \sigma b^{2}=\text { Variance of sample B } \\
& \mathrm{Na}=\text { Number of sample A } \\
& \mathrm{Nb}=\text { Number of sample B }
\end{aligned}
$$

\section{Decision Rule}

The decision rule for the t-test follows that we reject the null hypothesis at a given level of significance and degree of freedom given that the calculated t-value is greater that the critical t-value otherwise, the null hypothesis is rejected. The degree of freedom is given as $d / f=N a+N b-1$ while the $5 \%$ level of significance is adopted in this study.

The data used in the study are defined as follows:

$\mathrm{JSEb}=$ Junior Secondary School Enrollment before free and compulsory education JSEd = Junior Secondary School Enrollment during free and compulsory education $\mathrm{PSEb}=$ Primary School Enrollment before free and compulsory education 
PSEd = Primary School Enrollment during free and compulsory education

$\mathrm{SSEb}=$ Senior Secondary Enrollment before free and compulsory education

SSEd = Senior Secondary Enrollment during free and compulsory education

$\mathrm{SSCRb}=$ Senior Secondary Completion Rate before free and compulsory education SSCRd = Senior Secondary Completion Rate during free and compulsory education

\section{Findings AND Discussions Descriptive Statistics of the Data}

Table-1 represents the descriptive properties of the data employed in the data analysis. From the table, the enrollment and completion rates are captured for the primary, junior secondary and senior secondary school level.

Table-1: Descriptive properties of the data

\begin{tabular}{|l|l|l|l|l|l|l|}
\hline & Mean & Maximum & Minimum & Standard Deviation & Skewness & Kurtosis \\
\hline JSEb & 89,939 & 112,437 & 55,311 & 20,607 & -0.656 & 2.212 \\
\hline JSEd & 273,881 & 381,454 & 93,481 & 106,086 & -0.531 & 1.738 \\
\hline PSEb & 925,181 & 150,9209 & 101,159 & 473,858 & -0.073 & 2.153 \\
\hline PSEd & 924,240 & $1,008,339$ & 855,007 & 57,114 & 0.408 & 1.830 \\
\hline SSEb & 78,115 & 11,0042 & 40,735 & $23,948.59$ & -0.403 & 1.967 \\
\hline SSEd & 252,619 & 310,097 & 209,891 & $38,204.61$ & 0.220 & 1.530 \\
\hline SSCRb & 81.22 & 92.00 & 70.00 & 8.105 & 0.296 & 1.658 \\
\hline SSCRd & 89.27 & 92.83 & 83.00 & 3.637 & -0.582 & 1.851 \\
\hline \multicolumn{77}{|c|}{ Source: Author Computation } \\
\end{tabular}

Table-1 shows that enrollment rate before and during free and compulsory education at the senior secondary level averaged 78,115 and 252,619 respectively. This shows a substantial difference in the two periods as the average during the programme is far greater than when the programme was not implemented. Also, that of primary school enrollment averaged 925,181 and 924,240 for the two periods respectively, showing still a significant increase. Senior secondary school completion rate before and during free and compulsory education averaged 81.22 and 89.27 respectively, showing that the average completion rate is higher for the period of free and compulsory education in Akwa Ibom State. The Junior Secondary enrollment before free and compulsory education has the lowest standard deviation of 20,607 with a minimum value of 55,311 and a maximum value of 112,437 . The statistics were mostly skewed to the left at the primary and junior secondary levels. Also, the secondary school completion rate was skewed to the left before the implementation of the programme but afterwards, it becomes positively skewed.

\section{t - test Result}

The $\mathrm{t}-$ test result is presented in the Table-2.

Table-2: Students' t - test Result

\begin{tabular}{|l|l|l|l|}
\hline Item & Calculated t - value & Degree of Freedom & Decision \\
\hline Primary School Enrollment & 0.0059 & 17 & Insignificant \\
\hline Junior Secondary School Enrollment & -5.1062 & 17 & Significant \\
\hline Senior Secondary School Enrollment & -11.6103 & 17 & Significant \\
\hline Senior Secondary School Completion Rate & -2.7167 & 17 & Significant \\
\hline
\end{tabular}

Source: Author Computation

From Table-2 above, it is observed that there has been no significant difference between primary school enrollment in the period before the introduction of free and compulsory education and the period which the programme is initiated hence, the null hypothesis of no significant effect of free and compulsory education in Akwa Ibom State on school enrollment at the primary school level is accepted. Similarly, the junior secondary school enrollment and the senior school enrollment are seen to be significantly affected by the free and compulsory education policy. It is seen that there is a significant difference between junior secondary and senior secondary school enrollments in the period before free and compulsory education and the period during which the programme is initiated. Thus, the null hypothesis that there is no significant effect of the introduction of free and compulsory education in Akwa Ibom State on junior secondary school and senior secondary school enrollment are rejected at the $5 \%$ level of significance.

On the senior secondary school completion rate, it is observed that there is an existence of a significant difference between the completion rate within the period before free and compulsory education and the period of free and compulsory education. Thus, the null hypothesis that there is no significant effect of free and compulsory education in Akwa Ibom State on 
the secondary school completion rate is rejected at the $5 \%$ level of significance.

\section{Conclusion}

Free and compulsory education in Akwa Ibom state was, and still is crucial for the development of the state as it serves as an avenue for training the youths for the future challenge ahead. The study reveals that free and compulsory education has significant effect on the enrollment of students in the junior secondary and senior secondary level but shows no significant impact on primary school enrollment. On completion rate, this study reveals that the introduction of free and compulsory education has significantly impacted on the school completion rate at the senior secondary school level. Thus, there is need for a sustainable running of the programme so as to reap it fullest benefit of developing the state to a greater level and drastically eradicating illiteracy in accordance with the UBE policy objectives.

Free and compulsory education is an innovation and current trend in education aimed is to eradicate illiteracy, but this aim may be jeopardized by lack of educational resources, which can influence managerial effectiveness and the school climate with antecedent effects on the products of the free and compulsory education scheme. The paper concludes that resources availability relates significantly with effective implementation and achievement of the goal of free and compulsory education in Akwa Ibom State. Thus, efforts geared towards adequate provision of facilities should be made towards meeting the ever increasing enrollment rates in the school system. In line with the United Nations Organization's recommendation, the state government should continuously allocate $25 \%$ of the total budget for educational development

The Akwa Ibom state government, school heads, supervisors should ensure that school resources (desks, classrooms, libraries, laboratories) are made available in the right quality and quantity and appropriately managed to facilitate effective implementation of free and compulsory education at both the primary and Secondary School level in State. Adequate number of qualified teachers should be made available to schools with the teacher-students' ratio of 1:25 being maintained in in order to enhance effective teaching and learning.

\section{REFERENCES}

1. Kingdom, E. O., \& Maekae, J. (2013). The Role of Education in National Development: Nigerian Experience. European Scientific Journal, 9(28).

2. Denga, D. I. (1996). Human engineering for high productivity. Calabar: Rapid Educational Publishers Ltd.
3. Udoh, J. S. (2008). Points on Education: Principles and Practice. Uyo: Ntabeco Press Nigeria.

4. Otu, S. O., Charles, J. S., \& Akpabio, I. U. (2011). Entrepreneurship and functional teacher education as means of achieving the national objectives of vision 20; 2020 in Nigeria. Multidisciplinary Journal of Research Development (MULJORED), 17(4):16-23.

5. Amaele, S. (2001). Free education in Nigeria: Reality and implication. UBE Forum: Journal of Basic Education in Nigeria.

6. Salami, K. A. (2004). Provision and management of school facilities for the implementation of UBE. The Ogun state experience. In Fagbemiye, E. O., \& Babalola, J. B. (Eds): Management of Primary and Secondary Education in Nigeria. Ibadan. NAEP.

7. Universal Basic Education, UBE Digest, Nov. 2004.

8. Uyanga, R. E. (2012). The Provision of universal basic education in Nigeria. Challenges in the 21st century. International journal of diversity in organizations communities and nations, 11(6).

9. Federal Ministry of Education, Nigeria Education Indicators. Abuja, Nigeria, 2016.

10. Obanya, P. A. (2000). Ten questions Nigeria would answer about UBE. Daily Punch, December $4^{\text {th. }}$ 24-30.

11. Mincer, J. (1958). Investment in Human Capital and Personal Income Distribution. Journal of Political Economy, 66:281-302.

12. Schultz, T. W. (1961). Investment in Human Capital. American Economic Review, 51:1-17.

13. Ben-Porath, Y. (1967). The production of human capital and the life cycle of learnings. Journal of Political Economy, 75:352-365.

14. Bishop, J. (1977). The effect of public policies on the demand for higher education. Journal of Human Resources, 12: 285-307.

15. Kodde, D. A. (1986). Uncertainty and the Demand for Education. Review of Economics and Statistics, 68:460-467.

16. Nerlove, M. (1972). On tuition and the costs of higher education: prolegomena ion: A Conceptual Framework. Journal of Political Economy, 80:5178-5218.

17. Bos, D. (1980). The democratic Decision of Fees Versus Taxes. J Yklos, 23:76-99.

18. Arrow, K. A. (1973). Higher Education as a Filter. Journal of Public Economics, 2: 193-216.

19. Spence, L. (1973). Job Market Signaling. Quarterly Journal of Economics, 87:355-374.

20. Stiglitz, J. E. (1974). The Demand for Education in Public and Private School Systems. Journal of Public Economics, 3:349-385.

21. Rosenzweig, M. R. (1995). Why are there Returns to schooling? American Economic Review. Papers and Proceedings. 85:153-158. 
22. Hanushek, E. A. (1986). The Economics of Schooling: Production and Efficiency in Public schools. Journal of Economic Literature, 24:11411177.

23. Havema, R. H., \& Wolfe, B. L. (1984). Schooling and Economic Well-being: The Tale of Nonmarket Effects. Journal of Human Resources, 19:377407.

24. Babatunde, M. A., \& Adefabi, R. A. (2005). Long run relationship between education and economic growth in Nigeria: Evidence from the Johansen's cointegration approach. Department of economics, university of Ibadan, and Oyo State College of Education, Nigeria.

25. Lawanson, O. I. (2009). Human capital investment and economic development in Nigeria: The role of education and health. Proceeding $11^{\text {th }}$ OBEC Conference on Business \& Economics, 2009. 8 13, Oxford University, Oxford, UK.

26. Akpabio, I. U., \& Sammy, M. E. (2014). Implementing Free and Compulsory Education in
Secondary Schools in Akwa Ibom State Through Resources Availability: A Panacea for Achievement of Education for All (EFA)/ world Educators Forum.

27. Olefero, N. A., \& Anugwu, M. A. (2014). Massfication of student's intake and effectiveness of administration in public secondary schools in Akwa Ibom State, Nigeria. British Journal of Education. 2(6):19-29.

28. Federal Ministry of Education, Nigeria Digest of Education Statistics (2006 - 2010)". Abuja, Nigeria, 2011.

29. Federal Ministry of Education, Statistics of Education in Nigeria: 1999 - 2005. Abuja, Nigeria, 2007.

30. National Bureau of Statistics and UBEC, Education Data: Selected Basic Public Education Statistics in Nigeria 2013 - 2014". Abuja, Nigeria, 2016. 